\title{
Choreographic Practices
}

\section{Volume 10 Number 1}

\section{Backyard activisms: Site dance, permaculture and sustainability}

\section{Karen Barbour, The University of Waikato}

\section{Abstract}

Site dance performance offers creative opportunities for social and environmental activism. Conversely, social and environmental activism is becoming increasingly performative in seeking to evocatively engage a wide range of community members in both local and global concerns. The following pages focus on how research poetry arising in the creative process of developing performances of site dance may support activism. Drawing on interdisciplinary understandings of permaculture and sustainability and new approaches in narrative representation, the research poetry expresses backyard activism in a complementary manner to the site dance itself. The poetry synthesizes creative journal entries relating to somatic improvisation and choreography with dancers, and interviews and discussions with relevant community members. In Aotearoa New Zealand and in this wider neo-liberal era, urban residents are moving away from backyard gardening and local seasonal produce, and towards consumption of mass-produced, regulated and imported foods. In this context, community activism through performance may support local and alternative food movements and speak back to dominant, sociocultural and political power systems and norms relating to food production, consumption and sustainability. 


\section{Introduction}

Site dance offers a multitude of approaches both to creating dance that engages with specific sites and to cultivating responsive relationships and dialogues between places and dancers. Site dance is a growing research area in which particular artistic methods employed by choreographers and artists are nuanced in multiple ways in relation to the sites and places chosen for performance (Barbour et al. 2019; Hunter 2015; Kloetzel and Pavlik 2009). Alongside the wide range of site dance approaches, creative practice research provides a context for discussing interdisciplinary discourses and developing new methods. In the case of the site dance work Activisms discussed here, the discourses of permaculture, sustainability and activism influenced the dance created for an urban backyard garden (Barbour 2017). Each of these discourses of permaculture, sustainability and activism has a body of research within relevant disciplines. However, bringing dance and this interdisciplinary research together prompts a new and fruitful area of creative practice, one in which I, alongside others (Fraleigh 2015; Nelson 2018; Shapiro, 2008, 2016; Walla 2010), have recently been engaged. In an earlier issue of Choreographic Practices, Mathew Nelson (2018) offered a thought-provoking contribution, aligning dance and somatic practices with permaculture principles as embodied ecology. Nelson applied permaculture principles developed from David Holmgren's (2002) work into his eco-somatic improvisational workshop practice, particularly exploring 'themes of resilience, diversity, efficiency and ease [...] along with an ethical attitude of compassion' (Nelson 2018: 19). The embodied ecology approach that Nelson (2018) described resonates with improvisational practices undertaken in creating the site dance Activisms enacted in the context of an urban sustainable backyard garden (Barbour 2017).

In Aotearoa New Zealand, permaculture has helped to re-stimulate urban residents' interests in growing food and may contribute towards developing new relationships with food. 'Permaculture is one of the many postcapitalist ideas emerging from the margins: it's a revolution disguised as gardening', and aims to re-establish connections between people and environment, and between people and food production (The laboratory of insurrectionary imagination 2009: 5). Opportunities exist for urban residents to engage within community, school or backyard gardens, and through planting veranda pots or other areas such as berms (Brower 2013; Collins et al. 2015; Enviroschools n.d.; Jackson 2009; Longhurst 2006; Ritchie 2016). Such experiences may contribute towards improving wider community understandings of food production and consumption, general wellbeing across generations and cultures, and into the future. While my focus here is not to detail the nuances of either permaculture practice, or my somatic methods, I will examine the ways in which creative writing practices aligned with somatic methods resulted in activist research poetry that complemented the affective and embodied experiences of site dance. 
Research poetry arose during the creative process for Activisms created for the Sustainable Backyard Garden in urban Hamilton (Barbour 2017). Drawing on interdisciplinary understandings of permaculture and sustainability, and new approaches in narrative representation, the research poetry (Rinehart 2018) expressed backyard activism in a complementary manner to the site dance itself. Forms of spoken word, 'slam' and performance poetry offered opportunities to play with words, meanings and literary devices, and to embody the poetry in performance, enlivening words with performative rhythm, movement, expression, intonation and gesture. Performative poems typically express lived experiences in a personal, provocative and emotional style, including political 'rants' and personal 'pleas' relating to current events and injustices (Gregory 2008; Rivera 2013; Somers-Willet 2005). In this case, the poetry emerged during the process simultaneously with the choreography, both expressing lived experience, prompting discussion and generating awareness of action for change. Consequently, the performances expressed ecological and somatic, ethical and activist intentions through both movement and words. In this sense the performances offered, as Rivera wrote, 'an aesthetics of sociality, new economies and systems of artistic value that valorize connection and feeling in a contemporary social landscape that regularly attempts to convince itself of their irrelevance' (2013: 123). Before the poems and photographs are presented, I outline the methods used in this creative practice research project.

\section{Methods}

Beginning this creative practice research with performance poetry in mind, I integrated journal writing time with improvisational somatic tasks throughout so that the dancers and I could 'record' and 'interpret' our embodied experiences in words and drawings. While conducting interviews and discussions with key community members and engaging with particular interdisciplinary research, we collected a series of writings, and added as we responded to movement tasks, documented observations within the site of the Sustainable Backyard Garden, recorded new terminology, practices and principles related to permaculture. I then introduced the dancers to performance poetry and facilitated a process of creating performance ('slam') poems (Gregory 2008; Rivera 2013; Somers-Willet 2005).

The process for creating performance poems (adapted from workshops offered through New Zealand Poetry Slam [2018]) derived from the intention to have each performer create his or her own poem and movement phrase (a kind of 'slam solo'). The aim was that each poem would represent each dancer's ideas in a simple and relatable way that would immediately impact the audience with a clear message while also being rhythmic and passionate. The process began in a circle, brainstorming and playing word association on relevant topics relating to backyard gardens, food 
consumption and sustainability. A simple word quickly led to more complex ideas - e.g. 'food' lead to flavour, nourishment, nutrition, access, poverty, greed, obesity and hunger. Dancers then improvised individually, selected and refined movements from these words. Returning to the circle, the dancers shared movements and words, and each person responded with a word and movement. Repeatedly improvising in response to each other, we selected words and created movements using free association (words and movements as an immediate response to previous words and movements); alliteration (words or movements beginning with the same letter or movement); rhyming (words and movements with the same or very similar ending); synonyms (words that have similar meaning and movements that are variations of the same motifs); or acronyms (letters in a short recognizable form, or symbolic motifs that suggest a recognizable dance or action). Many of the words were then integrated into poems and the movements into choreography.

From this writing and improvising, each dancer selected a personally interesting theme and movements to create an individualized repertoire. To further develop poems and movement we applied choreographic principles and discussed 'the turn': the shift, high point or resolution in the structure. Each dancer created their own 'slam solo' and shared their poems. This material then became a resource for creating choreography for the larger work and for the development of finished poems to be included in the public performances. The following poems were performed during Activisms (Barbour 2017), and alongside the photographs they offer a representation of the activist intentions of this creative practice research for the context of the page. 


\section{Backyard gardens}

Here we are in this Waikato region

Blessed with fertile soil and high rainfall

Where once we produced food for all.

But now used to mass production and over-consumption Perhaps we've forgotten?

Our plants need companionship, just as people do Not mono-culturalism but bio-diversity too.

Yet we persist in genetically modifying seeds

Spraying pesticides, importing species

$$
\text { and killing the bees. }
$$

Maybe we can't feed the world's overpopulation

But let's not continue this indoctrination!

Slow down,

take a minute to breathe,

and think from global to local solutions.

What if we plant veggies and share them with friends Tomatoes and basil, cucumber and greens What if for the earth we really try to care, And for all people

As we deserve a fair share.

Green fingers and grass roots,

Cultivated ecology and respect for biology

New relationships with food and soil

under our boots.

Maybe gardening is a healthier aim

And backyards might flourish again.

Figure 1: Backyard gardens, bees at work in the Sustainable Backyard Garden. Photograph by Chloe Palmer 2017. 


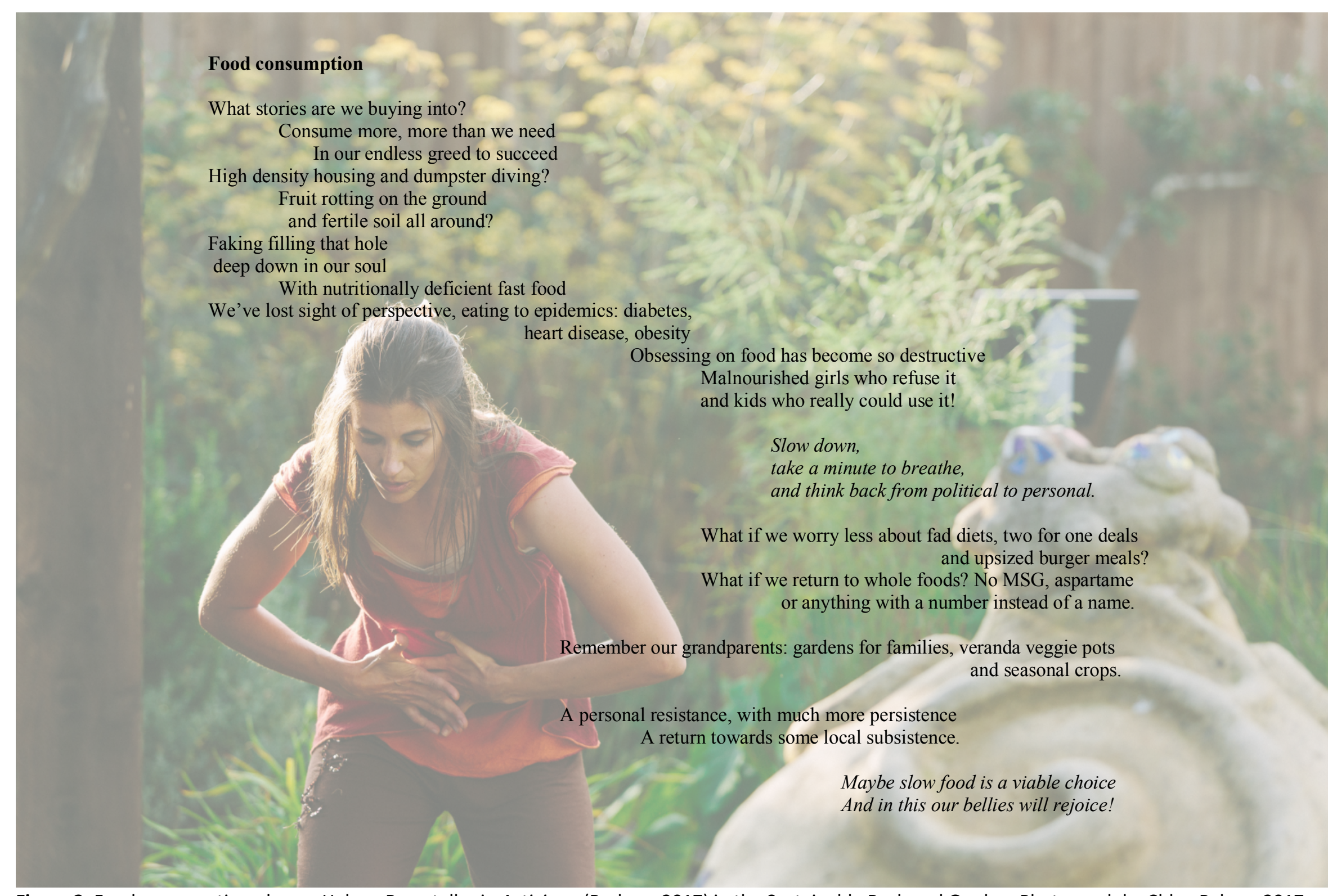

Figure 2: Food consumption, dancer Helene Burgstaller in Activisms (Barbour 2017) in the Sustainable Backyard Garden. Photograph by Chloe Palmer 2017. 


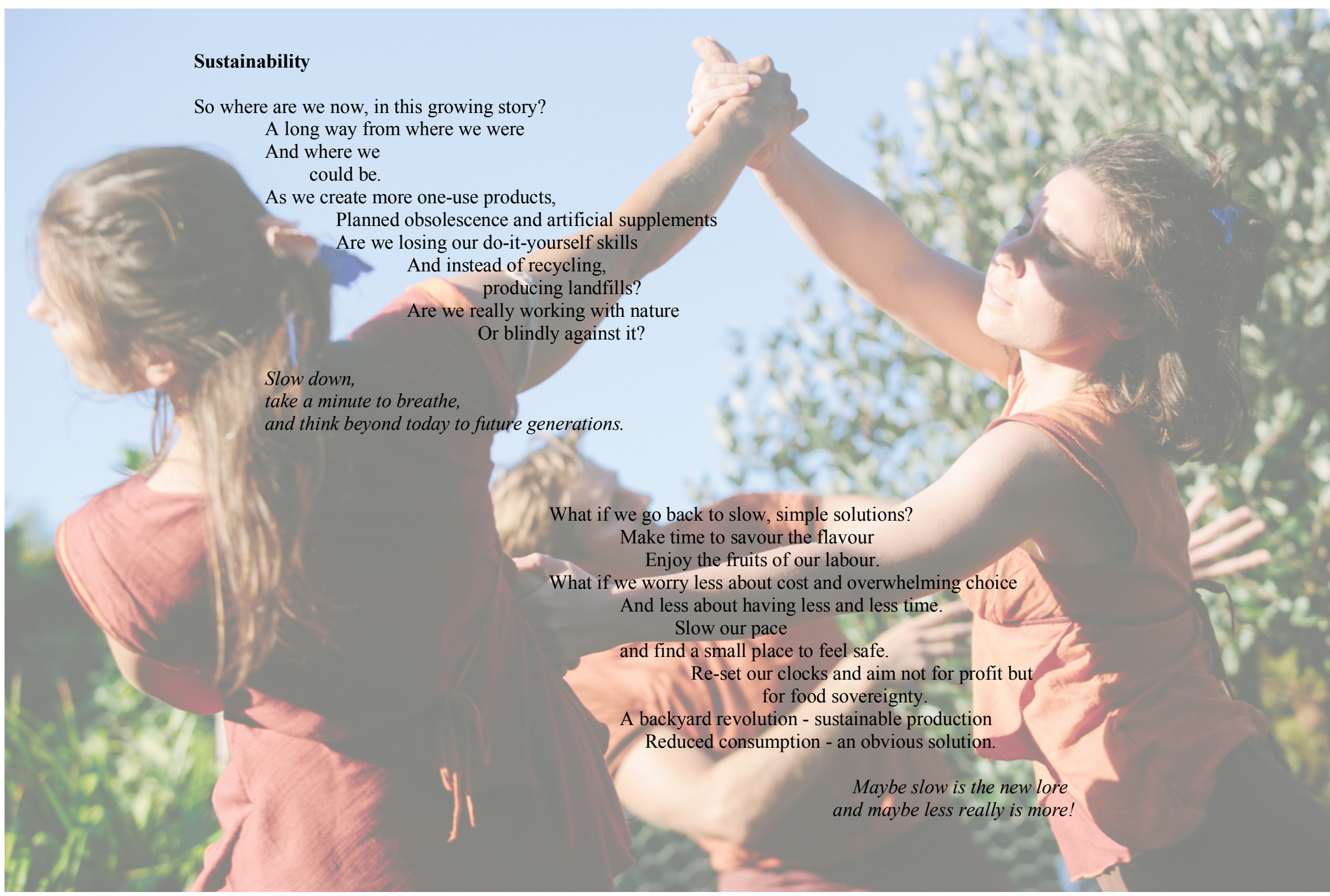

Figure 3: Sustainability, dancers at work in Activisms (Barbour 2017) in the Sustainable Backyard Garden. Photograph by Chloe Palmer 2017. 


\section{Reflections and conclusions}

The poems above reveal an alternative and complementary representation on the page of the site dance work, Activisms (Barbour 2017). While creating and performing this site dance our research deepened in permaculture, food production and consumption, and sustainability, within the creative process and also in raising personal and community awareness about gardening and well-being through the dance (Barbour 2017, 2008). In the wider context of performances such as site dances, sustainability may considered through,

the writing and production of plays (and dances) that directly address ecological questions, presenting them to audiences as consciousnessraising devices, or letting them emerge out of workshops in which the participants themselves engage with these issues and then develop a performance out of their investigations, debates and experiments, or indeed by questioning the sustainability (Clammer 2014: 67) of performance practices.

In Activisms (Barbour 2017), all three approaches to sustainability were embodied. Key ecological concerns about food production and consumption were raised with audiences during the performance, as illustrated in the poetry and photos above. The potential to raise awareness about ecological questions with audiences directly arose from the research discussions, interviews with dancers and colleagues, and observations of activities in the local community. Embodied responses surmised that we must take time in our families and communities to slow down and reflect, considering local, personal and futurefocused solutions that nevertheless engage with global, political issues. As specific practices, we investigated backyard gardening, choosing slow foods for well-being and an appreciation that less is more.

The sustainability of the creative process and performance practices were also relevant considerations, translating into negotiable working relationships around schedules, roles and payment, and managing the commitments of everyday life alongside dance making (Barbour 2008). More specific embodied practices included structuring rest periods and alternating central roles within the choreography, deliberately incorporating pleasurable interactions with favoured plants and areas of the garden, inviting family and friends to join us during rehearsals, sharing gardening knowledge and experiences, and including sharing food amongst ourselves.

Alongside this deepening understanding of sustainability in terms of site dance creative process and performance was the very important realization that there are many other values of gardening that are not only about food. These values include embodied experiences of land, weather, seasons and interaction with plants and healthy soil microbiota (Kemper and Lal 2017; Kolich 2013; Puig de la Bellacassa 2015). The pleasures of the physical activity of gardening for leisure and of aromatic and 
visually aesthetic planting may support stress relief and offer an experience of spirituality for some (Unruh and Hutchinson 2011). Retaining embodied memories of gardening and sharing knowledge through intergenerational exchange are also important values. In addition, scholars focused on community gardening particularly advocate participation as a form of active citizenship within the neo-liberal era (Crossan et al. 2016; Ghose and Pettygrove 2014). All of the above values are expressed in gardening and have potential personal, physical, social, affective emotional and spiritual benefits for our well-being, further supporting sustainable practices (Hayes-Conroy and Hayes-Conroy 2013; Kemper and Lal 2017; Unruh and Hutchinson 2011).

Considering the wider sociocultural implications of this urban site dance research, we came to an embodied understanding that a long-term and sustainable approach to transforming local and global practices around food production and consumption is necessary. It has been argued that 'food activism reproduces the very neoliberal forms and subjectivities that it seeks to oppose, pointing to the reoccurring themes of consumer choice, localism, entrepreneurialism and self-improvement as intersecting with neoliberal rationalities' (Brower 2013: 82). Such forces inevitably affect choices around food. Local alternative food initiatives may not engage with wider social justice and equity issues. Family and community choices to garden in backyards (noting that owning a home and backyard garden has become an unattainable goal for many New Zealanders [Longhurst 2006]) may have valuable personal impact but negligible local impact for those unable to garden, and no impact on global food sustainability. Practices of conscious consumerism, which can feel like an overwhelming responsibility for individuals to make informed choices within this neo-liberal era, may have far less impact than donating money to an environmental lobby group (Ritchie 2016). Instead,

Transformation implies long-term, systemic, and cross-cutting change to existing social, economic and political decision-making processes... These changes are required to improve human equality and wellbeing, particularly of the poor and marginalised. Specific processes and principles that enable social change include bottom-up collective action, decentralisation, local innovation responses, inclusive governance and collective ideas of wellbeing. (Duell 2013: 130)

Irrespective of such critiques, it is still important to celebrate practices that demonstrate personal and local, grass-roots responses and collective ideas of well-being. As revealed in the creative process and represented above, there is potential for fostering an embodied experience of resistance and well-being through local activism that may support movement towards personal, family and community change. From this experience of education through local activism, potential action for wider political change may arise. It may be simply that gardening is the beginning of broader social activism. 


\section{Acknowledgements}

Thanks are due to the research assistants and performers in this project Helene Burgstaller, Geoff Gilson and Gabriel Baker, and to photographer Chloe Palmer for permission to use photos taken of the site dance Activisms (Barbour 2017).

\section{References}

Barbour, Karen N. (2008), 'Sustainable dance making: Dancers and choreographers in collaboration', Brolga, 28:1, June, pp. 41-51.

___ (2017), 'Activisms [dance season]', Hamilton Gardens Arts Festival, Sustainable Backyard Garden, Hamilton Gardens, 21-23 February.

Barbour, Karen N., Hunter, Vicky and Kloetzel, Melanie (2019), (Re)Positioning Site Dance: Local Acts, Global Perspectives, Bristol: Intellect Books.

Brower, Andrea (2013), 'Agri-food activism and the imagination of the possible', New Zealand Sociology, 28:4, pp. 80-100.

Carolan, Michael (2013), 'Final word: Putting the "alter" in alternative food futures', New Zealand Sociology, 28:4, pp. 145-50.

Clammer, John (2014), 'Art and the arts of sustainability', Social Alternatives, 33:3, pp. 65-70.

Collins, Carly, Richards, Rosalina, Reeder, Antony I. and Gray, Andrew R. (2015), 'Food for thought: Edible gardens in New Zealand primary and secondary schools', Health Promotion Journal of Australia, 26, pp. 70-73.

Crossan, John, Cumbers, Aandrew, McMaster, Robert and Shaw, Deidre (2016), 'Contesting neoliberal urbanism in Glasgow's community gardens: The practice of DIY citizenship', Antipode, 48:4, pp. 937-55.

Duell, Rebecca (2013), 'Is “local food” sustainable? Localism, social justice, equity and sustainable food futures', New Zealand Sociology, 28:4, pp. 123-44.

Enviroschools (n.d.), 'Tā tātou kaupapa: About enviroschools', http://www.enviroschools.org.nz/about-enviroschools. Accessed 2702 2019..

Forster, Margaret (2013), 'Imagining new futures: Kaitiakitanga and agri-foods', New Zealand Sociology, 28:4, pp. 9-32.

Fraleigh, Sondra (ed.) (2015), Moving Consciously: Somatic Transformations through Dance, Yoga and Touch, Urbana, Chicago and Springfield, IL: University of Illinois Press.

Ghose, Rina and Pettygrove, Margaret (2014), 'Urban community gardens as spaces of citizenship', Antipode, 46:4, pp. 1092-112. 
Grant, Adrienne and Snowdon, Melanie (2001), How to Grow Your Own Food. Creating and Maintaining an Organic Vegetable Garden, Hamilton: Hamilton Permaculture Trust.

Grauerholz, Liz and Owens, Nicole (2015), 'Alternative food movements', in James D. Wright (ed), International Encyclopedia of the Social \& Behavioral Sciences, 2nd ed., vol. 1, pp. 566-72, http://dx.doi.org/10.1016/B978-0-08-097086-8.64133-8.

Gregory, Helen (2008), 'The quiet revolution of poetry slam: The sustainability of cultural capital in the light of changing artistic conventions', Ethnography and Education, 3:1, pp. 63-80.

Hayes-Conroy, Jessica and Hayes-Conroy, Allison (2013), 'Veggies and visceralities: A political ecology of food and feeling', Emotion, Space and Society, 6, pp. 81-90.

Holmgren, David (2002), Permaculture: Principles and Pathways Beyond Sustainability, Victoria: Holmgren Design Services.

Hunter, Vicky (ed.) (2015), Moving Sites. Investigating Site-Specific Dance Performance, London and New York: Routledge.

Jackson, Samantha (2009), 'Enviroschools in New Zealand', MAl Review, 1, Intern Research Report 5, pp1-8.

Jamieson, Colin (2015), 'The shrinking of New Zealand's quarter-acre paradise', Australian Garden History, 27:2, October, pp. 16-18.

Kemper, Kathi J. and Lal, Rattan (2017), 'Editorial: Pay dirt! Human health depends on soil health', Complementary Therapies in Medicine, 32, pp. A1-A2.

Kloetzel, Melanie and Pavlik, Carolyn (eds) (2009), Site Dance: Choreographers and the Lure of Alternative Spaces, Gainesville, FL: University Press of Florida.

Kolich, Heather N. (2013), 'From the ground up', Vibrant Life, 29:4, July/August, pp. 38-39.

Longhurst, Robyn (2006), 'Plots, plants and paradoxes: Contemporary domestic gardens in Aotearoa/New Zealand', Social \& Cultural Geography, 7:4, pp. 581-93.

Mollison, Bill and Slay, Reny M. (1991). Introduction to Permaculture, Tyalgum: Tagari Publishers.

Nelson, Matthew (2018), 'Embodied ecology: The eco-somatics of permaculture', Choreographic Practices, 9:1, pp. 17-30.

New Zealand Poetry Slam (2018), 'Tutoring and youth slam', http://www.newzealandpoetryslam.com/youth.html. Accessed 2702 2019.

Olsen, Andrea (2002), Body and Earth. An Experiential Guide, Lebanon, NH: University of New England.

Perkins, Harvey C. and Thorns, David C. (1999), 'House and home and their interaction with changes in New Zealand's urban system, households and family structures, housing, theory and society', 16:3, pp. 124-35. 
Puig de la Bellacassa, Maria (2015), 'Making time for soil: Technoscientific futurity and the pace of care', Social Studies of Science, $45: 5$, pp. $691-716$.

Rinehart, Robert E. (2018), 'Poetry and science: Understanding and knowledge', The Ethnograhic Edge, 2:1, pp. 1-7, http://dx.doi.org/10.15663/tee.v2i1.42.

Ritchie, Isa (2016), 'Food sovereignty in Whaingaroa: Perspectives of food providers in a small, coastal New Zealand township', Anthropological Forum, 26:3, pp. 289-300.

Rivera, Takeo (2013), 'You have to be what you're talking about: Youth poets, amateur counter-conduct, and parrhesiastic value in the amateur youth poetry slam', Performance Research, 18:2, pp. 114-23.

Shapiro, Sherry B. (ed.) (2008), Dance in a World of Change. Reflections on Globalization and Cultural Difference, Champaign, IL: Human Kinetics.

(2016), 'Dance as activism: The power to envision, move and change', Dance Research Aotearoa, 4:1, pp. 3-33.

Somers-Willett and Susan B. A. (2005), 'Slam poetry and the cultural politics of performing identity', The Journal of the Midwest Modern Language Association, 38:1, Spring, pp. 51-73.

The Laboratory of Insurrectionary Imagination (2009), 13 Attitudes, London: The Laboratory of Insurrectionary Imagination, http://www.labofii.net.

United Nations (2015), 'Sustainable development goals: 17 goals to transform our world', https://www.un.org/sustainabledevelopment/. Accessed 27 02 2019.

Unruh, Anita and Hutchinson, Susan (2011), 'Embedded spirituality: Gardening in daily life and stressful life experiences', Scandinavian Journal of Caring Sciences, 25, pp. 567-74.

Walla, Nala (2010), 'Body as place: A somatic guide to re-indigenization', in Martin Keogh (ed.), Hope Beneath our Feet: Restoring Our Place in the Natural World, Berkeley, CA: North Atlantic Books, pp. 150-57.

\section{Contributor details}

Karen Barbour is an associate professor in dance in the School of Arts at The University of Waikato in Aotearoa New Zealand. Her teaching, performance and research focuses on embodied ways of knowing particularly feminist choreographic practices in dance, site-specific, digital dance and 
pedagogical movement contexts. Her book publications include Dancing Across the Page: Narrative and Embodied Ways of Knowing (Barbour 2011), (Re)Positioning Site Dance: Local Acts, Global Perspectives (Barbour et al. 2019) and Ethnographic Worldviews: Transformations and Social Justice (Rinehart et al. 2014). Karen is editor of the journal Dance Research Aotearoa, presents regularly at international conferences and has published her writing in a range of books and journals.

Contact:

School of Arts, The University of Waikato, Private Bag 3105, Hamilton 3240, New Zealand.

E-mail: karen.barbour@waikato.ac.nz

https://orcid.org/0000-0002-6262-7146 